\title{
MMR
}

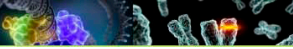

\section{Association between IL-10-G1082A polymorphisms and the development of coronary artery disease in a Chinese population}

\author{
K. Liang, S.R. Dong and H. Peng \\ Department of Cardiovascular Disease, \\ the Fifth Affiliated Hospital of Zhengzhou University, \\ Zhengzhou, Henan, China \\ Corresponding author: K. Liang \\ E-mail: liangkunr@163.com
}

Genet. Mol. Res. 15 (2): gmr.15027933

Received October 27, 2015

Accepted January 18, 2016

Published April 27, 2016

DOI http://dx.doi.org/10.4238/gmr.15027933

\begin{abstract}
We conducted a case-control study to investigate the association between IL-10-G1082A (rs1800896) polymorphism and the development of coronary artery disease (CAD) in the Chinese population. We recruited $295 \mathrm{CAD}$ patients and 355 healthy controls from the Fifth Affiliated Hospital of Zhengzhou University between April 2012 and December 2014. Subjects were genotyped for $I L-10$ G1082A polymorphisms by using polymerase chain reaction-restriction fragment length polymorphism. We observed significant differences in the genotype frequencies of $\mathrm{GG}, \mathrm{AG}$, and AA between CAD patients and controls $\left(\chi^{2}=17.38, \mathrm{P}<0.001\right)$. Multivariate logistic regression analyses revealed that individuals with the AA genotype at $I L-10$ $1082 \mathrm{~A} / \mathrm{G}$ was associated with increased risk for CAD as compared to those with the GG genotype $(\mathrm{OR}=2.96,95 \% \mathrm{CI}=1.70-5.23, \mathrm{P}<$ $0.001)$. Our results indicated that $I L-10-1082 \mathrm{~A} / \mathrm{G}$ polymorphism was associated with susceptibility to CAD in both dominant $(\mathrm{OR}=1.59$,
\end{abstract}


$95 \% \mathrm{CI}=1.15-2.20, \mathrm{P}=0.004)$ and recessive $(\mathrm{OR}=2.58,95 \% \mathrm{CI}=1.53-$ $4.45, \mathrm{P}<0.001)$ models. In conclusion, our study suggests that $I L-10$ $1082 \mathrm{~A} / \mathrm{G}$ polymorphism is associated with an increased risk for CAD.

Key words: $I L-10-1082 \mathrm{~A} / \mathrm{G}$; Polymorphism; Coronary artery disease

\section{INTRODUCTION}

Cardiovascular disease is a complex and serious disease, associated with high morbidity and mortality worldwide (He et al., 2005; Go et al., 2014). Coronary artery disease (CAD) is one of the most common cardiovascular diseases. It is well known that CAD arises due to multiple lifestyle and environmental factors such as hypertension, diabetes, tobacco smoking and family history of hypertension (Jayashree et al., 2015; Chhabra et al., 2016). However, detailed etiology of this disease is not well understood. Moreover, it is reported that genetic factors also contribute to the development of CAD. Previous studies have reported that several genetic factors such as monocyte chemoattractant protein-1 (MCP-1), fatty acid desaturase 1/2 (FADS1/FADS2), cyclooxygenase-2 (COX-2), and matrix metalloproteinase-2 (MMP-2) play important roles in the development of CAD (Angeles-Martínez et al., 2015; Shi et al., 2015a; Yang et al., 2015; Zhang et al., 2015).

Previous studies reported that cytokines play an important role in the migration of neutrophils, lymphocytes, as well as antigen-presenting cells, and thus contribute to the inflammatory response elicited during CAD development (Sun et al., 2014; Oikonomou et al., 2014; Shi et al., 2015b). Previous studies have associated $I L-10-G 1082 \mathrm{~A}$ polymorphism with risk for CAD; however, the results were inconclusive (Karaca et al., 2011; Guo et al., 2012; Chao et al., 2014; Elsaid et al., 2014; Lin et al., 2014; Ren and She, 2015). Therefore, we conducted a case-control study to investigate the association between $I L-10-G 1082 \mathrm{~A}$ (rs 1800896) polymorphism and development of CAD in the Chinese population.

\section{MATERIAL AND METHODS}

\section{Patients}

CAD patients (295) were recruited from the Fifth Affiliated Hospital of Zhengzhou University between April 2012 and December 2014. All patients with CAD underwent coronary angiography according to standardized protocols and were independently diagnosed by two cardiologists. CAD patients had a history of a myocardial bridge, serious kidney or liver diseases, as well as malignant tumors were excluded from our study.

Healthy controls (355) were randomly selected from individuals who underwent health examinations and coronary angiography. All control subjects were confirmed to be free of CAD, and had no history of arteriosclerotic lesions. Control subjects who had a myocardial bridge, congenital heart diseases, childhood hypertension, serious kidney or liver diseases, as well as cancers were also excluded from this study.

The demographic characteristics of all study subjects were collected from structured questionnaires, which included information regarding sex, age, alcohol consumption, and tobacco smoking. Clinical information was collected from medical records, which included TC, LDL-c, HDL-c, and TG levels. 
Blood sample $(5 \mathrm{~mL})$ was obtained from each patient and control for analysis, and the written informed consent form was signed by all study subjects prior to their participation in the study. The study protocol was approved by the Ethics Committee of the Fifth Affiliated Hospital of Zhengzhou University.

\section{DNA extraction and SNP genotyping}

DNA was extracted from peripheral blood leukocytes by using a TIANamp Blood DNA Kit (Tiangen Biotech, Beijing, China) according to the manufacturer instructions. $I L-10-G 1082 \mathrm{~A}$ polymorphism was genotyped using polymerase chain reaction-restriction fragment length polymorphism (PCR-RFLP). Forward and reverse primers of $I L$ 10-G1082A for PCR were as follows: 5'-CCAAGACAACTAAGGCTCCTTT-3' and 5'-GCTTCTTATATGCTAGTCAGGTA-3'. Amplified gene product was digested with the restriction enzyme $M n l l$, and the length of the digested fragment for $I L-10-G 1082 \mathrm{~A}$ was 139 bp. The length of the digested fragment for the A allele was $139 \mathrm{bp}$, while that for those of the G allele was 106 and $33 \mathrm{bp}$. The reaction conditions for PCR were as follows: one cycle of initial DNA denaturation at $94^{\circ} \mathrm{C}$ for $5 \mathrm{~min} ; 30$ cycles of denaturation at $94^{\circ} \mathrm{C}$ for $1 \mathrm{~min}$, annealing at $55^{\circ} \mathrm{C}$ for $1 \mathrm{~min}$, extension at $72^{\circ} \mathrm{C}$ for $2 \mathrm{~min}$; and final extension was carried out at $72^{\circ} \mathrm{C}$ for $5 \mathrm{~min}$. The PCR products were analyzed by electrophoresis on a $2 \%$ agarose gel and stained with ethidium bromide. The DNA bands were visualized under UV light.

\section{Statistical analysis}

The demographic and clinical characteristics, as well as $I L-10-$ G1082A genotype frequencies in patients with CAD and control subjects were compared using chi-squared $\left(\chi^{2}\right)$ tests or Student's $t$-test. The goodness-of-fit $\chi^{2}$-test was carried out in all patient and control samples to determine whether the genotype frequencies at $I L-10-\mathrm{G} 1082 \mathrm{~A}$ deviated from the Hardy-Weinberg equilibrium (HWE). Unconditional logistic regression analysis was conducted to assess the role of $I L-10-\mathrm{G} 1082 \mathrm{~A}$ in the development of CAD, and the results were analyzed by OR and 95\%CI. Statistical analysis was conducted using the SPSS 16.0 software, and $\mathrm{P}<0.05$ was considered statistically significant.

\section{RESULTS}

The distributions of demographic and clinical characteristics of study subjects are summarized in Table 1. The mean ages of CAD patients and controls were $58.65 \pm 11.62$ and $57.53 \pm 12.15$ years, respectively. We did not find any significant differences between CAD patients and controls in terms of age $\left(\chi^{2}=1.19, \mathrm{P}=0.12\right)$, sex $\left(\chi^{2}=0.007, \mathrm{P}=0.94\right)$, or alcohol consumption $\left(\chi^{2}=3.18, \mathrm{P}=0.07\right)$. As compared to the control group, we found that patients with CAD had a habit of tobacco smoking $\left(\chi^{2}=61.13, \mathrm{P}<0.001\right)$, higher TC $\left(\chi^{2}=7.17, \mathrm{P}<\right.$ $0.001)$, LDL-c $\left(\chi^{2}=4.79, \mathrm{P}<0.001\right)$, and TG levels $\left(\chi^{2}=10.37, \mathrm{P}<0.001\right)$, but lower HDL-c levels $\left(\chi^{2}=5.17, \mathrm{P}<0.001\right)$.

We also observed significant differences in the genotype frequencies of GG, AG, and AA between CAD patients and controls $\left(\chi^{2}=17.38, \mathrm{P}<0.001\right)$ (Table 2). The genotypic distributions of $I L-10-1082 \mathrm{~A} / \mathrm{G}$ in the CAD patients and control subjects did not deviate from the Hardy-Weinberg equilibrium, and the P values were 0.08 and 0.78 , respectively. Moreover, 
K. Liang et al.

the calculated minor allele frequencies of $I L-10-1082 \mathrm{~A} / \mathrm{G}$ in controls were similar to those obtained from the National Center for Biotechnology Information SNP database.

Multivariate logistic regression analyses revealed that individuals with the AA genotype at $I L-10-1082 \mathrm{~A} / \mathrm{G}$ were at increased risk for CAD as compared to those with the GG genotype $(\mathrm{OR}=2.96,95 \% \mathrm{CI}=1.70-5.23, \mathrm{P}<0.001)$ (Table 3$)$. In the dominant model, compared to the GG genotype, the AG + AA genotype was associated with an elevated risk for $\mathrm{CAD}(\mathrm{OR}=1.59,95 \% \mathrm{CI}=1.15-2.20, \mathrm{P}=0.004)$. In addition, the AA genotype was associated with increased risk of CAD as compared with the $\mathrm{GG}+\mathrm{AG}$ genotype in a recessive model $(\mathrm{OR}=2.58,95 \% \mathrm{CI}=1.53-4.45)$.

Table 1. Demographic and clinical characteristics of study subjects.

\begin{tabular}{|c|c|c|c|c|c|c|}
\hline & CAD patients $(\mathrm{N}=295)$ & $\%$ & Controls $(\mathrm{N}=355)$ & $\%$ & $\chi^{2}$ test or $t$-test & $P$ value \\
\hline Mean age (years) & $58.65 \pm 11.62$ & & $57.53 \pm 12.15$ & & 1.19 & 0.12 \\
\hline \multicolumn{7}{|l|}{ Gender } \\
\hline Male & 226 & 76.61 & 271 & 76.34 & & \\
\hline Female & 69 & 23.39 & 84 & 23.66 & 0.007 & 0.94 \\
\hline \multicolumn{7}{|c|}{ Alcohol consumption } \\
\hline Never & 143 & 48.47 & 197 & 55.49 & & \\
\hline Current or ever & 152 & 51.53 & 158 & 44.51 & 3.18 & 0.07 \\
\hline \multicolumn{7}{|l|}{ Tobacco smoking } \\
\hline Never & 125 & 42.37 & 258 & 72.68 & & \\
\hline Current or ever & 170 & 57.63 & 97 & 27.45 & 61.13 & $<0.001$ \\
\hline TC (mM) & $188.22 \pm 34.13$ & & $169.30 \pm 32.94$ & & 7.17 & $<0.001$ \\
\hline LDL-c (mM) & $114.21 \pm 24.53$ & & $105.32 \pm 22.74$ & & 4.79 & $<0.001$ \\
\hline HDL-c (mM) & $38.47 \pm 18.10$ & & $44.52 \pm 11.47$ & & 5.17 & $<0.001$ \\
\hline TG $(\mathrm{mM})$ & $142.91 \pm 31.58$ & & $119.47 \pm 26.04$ & & 10.37 & $<0.001$ \\
\hline
\end{tabular}

Table 2. Genotype distributions of $I L-10-1082 \mathrm{~A} /$ Gin CAD patients and healthy control subjects.

\begin{tabular}{|c|c|c|c|c|c|c|c|c|c|c|}
\hline \multirow{2}{*}{$I L-10-1082 \mathrm{~A} / \mathrm{G}$} & \multirow{2}{*}{ Patients $(\mathrm{N}=295)$} & \multirow[t]{2}{*}{$\%$} & \multirow{2}{*}{ Controls $(\mathrm{N}=355)$} & \multirow[t]{2}{*}{$\%$} & \multicolumn{2}{|c|}{$P$ for HWE } & \multirow{2}{*}{$\chi^{2}$-test } & \multirow{2}{*}{$P$ value } & \multicolumn{2}{|c|}{ Minor allele frequency } \\
\hline & & & & & In cases & In controls & & & In database & In controls \\
\hline rs1800896 & & & & & & & & & & \\
\hline GG & 120 & 40.68 & 185 & 52.11 & & & & & & \\
\hline$\overline{\mathrm{AG}}$ & 125 & 42.37 & 144 & 40.56 & & & & & & \\
\hline $\mathrm{AA}$ & 50 & 16.95 & 26 & 7.32 & 0.08 & 0.78 & 17.38 & $<0.001$ & 0.2722 & 0.2761 \\
\hline
\end{tabular}

Table 3. Association between $I L-10-1082 \mathrm{~A} / \mathrm{G}$ polymorphism and the risk of CAD.

\begin{tabular}{|c|c|c|c|c|c|c|}
\hline$I L-10-1082 \mathrm{~A} / \mathrm{G}$ & Patients $(\mathrm{N}=295)$ & $\%$ & Controls $(\mathrm{N}=355)$ & $\%$ & OR $(95 \% \mathrm{CI})^{1}$ & $P$ value \\
\hline \multicolumn{7}{|l|}{ Co-dominant } \\
\hline GG & 120 & 40.68 & 185 & 52.11 & Reference group & - \\
\hline$\overline{A G}$ & 125 & 42.37 & 144 & 40.56 & $1.34(0.95-1.89)$ & 0.09 \\
\hline AA & 50 & 16.95 & 26 & 7.32 & $2.96(1.70-5.23)$ & $<0.001$ \\
\hline \multicolumn{7}{|l|}{ Dominant } \\
\hline GG & 120 & 40.68 & 185 & 52.11 & Reference group & - \\
\hline $\mathrm{AG}+\mathrm{AA}$ & 175 & 59.32 & 170 & 47.89 & $1.59(1.15-2.20)$ & 0.004 \\
\hline \multicolumn{7}{|l|}{ Recessive } \\
\hline $\mathrm{GG}+\mathrm{AG}$ & 245 & 83.05 & 329 & 92.68 & Reference group & - \\
\hline AA & 50 & 16.95 & 26 & 7.32 & $2.58(1.53-4.45)$ & $<0.001$ \\
\hline
\end{tabular}

${ }^{1}$ Adjusted for gender, age, tobacco smoking, TC, LDL-c, HDL-c, and TG.

\section{DISCUSSION}

In this hospital-based case-control study, we assessed the role of $I L-10-1082 \mathrm{~A} / \mathrm{G}$ gene polymorphism (rs1800896) in the development of CAD. Our results indicated that $I L-10$ $1082 \mathrm{~A} / \mathrm{G}$ polymorphism is associated with an increased risk of CAD. 
Previous studies have reported that $I L-10-1082 \mathrm{~A} / \mathrm{G}$ polymorphism was associated with various diseases such as Graves' disease, liver cirrhosis, ischemic stroke, deep venous thrombosis, and atopic asthma (Jin et al., 2014; Tang et al., 2014; Zheng et al., 2014; Guo et al., 2015; Liang et al., 2015). Zheng et al. (2014) conducted a meta-analysis with 4,716 asthmatic patients and 5,093 controls, and reported that $I L-10$ promoter-1028A/G polymorphism was associated with susceptibility to asthma. Tang et al. (2014) conducted a case-control study on patients with deep venous thrombosis, and reported that $I L-10-1082 \mathrm{~A} / \mathrm{G}$ polymorphism was correlated with the development of deep venous thrombosis. A meta-analysis by Jin et al. (2014), which consisted of seven independent studies, showed that $I L-10-1082 \mathrm{~A} / \mathrm{G}$ polymorphism was associated with ischemic stroke in Asians. Guo et al. (2015) conducted a meta-analysis consisting of 12 independent studies and reported that $I L-10-1082 \mathrm{~A} / \mathrm{G}$ polymorphism did not contribute to HCV-related liver cirrhosis. In a case-control study by Liang et al. (2015), it was reported that $I L-10-1082 \mathrm{~A} / \mathrm{G}$ polymorphism was a predictive biomarker for Graves' diseases.

Several previous studies reported an association between $I L-10-1082 \mathrm{~A} / \mathrm{G}$ polymorphism and the development of coronary artery diseases; however, the results were inconclusive (Guo et al., 2012; Elsaid et al., 2014; Li et al., 2015; Ren and She, 2015). Li et al. (2015) conducted a case-control study in the Chinese population and did not find any association between $I L-10-1082 \mathrm{~A} / \mathrm{G}$ polymorphism and the risk of coronary artery diseases. Similarly, Guo et al. (2012) reported that $I L-10-1082 \mathrm{~A} / \mathrm{G}$ polymorphism is unlikely to be associated with CAD. In contrast, a study by Ren and She (2015) with 325 CAD patients and 342 controls reported that $I L-10-1082 \mathrm{~A} / \mathrm{G}$ polymorphism contributes to the risk for $\mathrm{CAD}$, especially in individuals with hypertension or diabetes mellitus, as well as in smokers. This was confirmed in a study by Elsaid et al. (2014), which suggested that $I L-10-1082 \mathrm{~A} / \mathrm{G}$ polymorphism is associated with an increased susceptibility to CAD. Two previous metaanalyses have also reported that the GA + AA genotypes were associated with an increased risk for CAD and atherosclerosis (Wang et al., 2012; Chao et al., 2014). In our study, we found that the AA and AG + AA genotypes were associated with the development of CAD. Further studies are needed to confirm our findings.

In conclusion, our results suggest that $I L-10-1082 \mathrm{~A} / \mathrm{G}$ polymorphism is associated with an increased risk for CAD. Future studies conducted in patients of different ethnic backgrounds and in a larger cohort may help elucidate the impact of these polymorphisms on the development of CAD.

\section{Conflicts of interest}

The authors declare no conflicts of interest.

\section{ACKNOWLEDGMENTS}

We thanks for the helps from staffs in Fifth Affiliated Hospital of Zhengzhou University who help us to collected information from questionnaires and medical records.

\section{REFERENCES}

Angeles-Martínez J, Posadas-Sánchez R, Álvarez-León E, Villarreal-Molina T, et al. (2015). Monocyte chemoattractant protein-1 gene (MCP-1) polymorphisms are associated with risk of premature coronary artery disease in Mexican 
patients from the Genetics of Atherosclerotic Disease (GEA) study. Immunol. Lett. 167: 125-130. http://dx.doi. org/10.1016/j.imlet.2015.08.003

Chao L, Lei H and Fei J (2014). A meta-analysis of interleukin-10-1082 promoter genetic polymorphism associated with atherosclerotic risk. Neurol. India 62: 130-136. http://dx.doi.org/10.4103/0028-3886.132323

Chhabra L, Ahlberg AW, Henzlova MJ and Duvall WL (2016). Temporal trends of stress myocardial perfusion imaging: Influence of diabetes, gender and coronary artery disease status. Int. J. Cardiol. 202: 922-929. http://dx.doi. org/10.1016/j.ijcard.2015.09.020

Elsaid A, Abdel-Aziz AF, Elmougy R and Elwaseef AM (2014). Association of polymorphisms G(-174)C in IL-6 gene and G(-1082)A in IL-10 gene with traditional cardiovascular risk factors in patients with coronary artery disease. Indian J. Biochem. Biophys. 51: 282-292.

Go AS, Mozaffarian D, Roger VL, Benjamin EJ, et al.; American Heart Association Statistics Committee and Stroke Statistics Subcommittee (2014). Heart disease and stroke statistics--2014 update: a report from the American Heart Association. Circulation 129: e28-e292. http://dx.doi.org/10.1161/01.cir.0000441139.02102.80

Guo J, He YH, Chen F, Jiang MH, et al. (2012). The A to G polymorphism at -1082 of the interleukin-10 gene is rare in the Han Chinese population. Mol. Med. Rep. 6: 894-896.

Guo PF, Jin J and Sun X (2015). Influence of IL10 gene polymorphisms on the severity of liver fibrosis and susceptibility to liver cirrhosis in HBV/HCV-infected patients. Infect. Genet. Evol. 30: 89-95. http://dx.doi.org/10.1016/j. meegid.2014.12.011

He J, Gu D, Wu X, Reynolds K, et al. (2005). Major causes of death among men and women in China. N. Engl. J. Med. 353: 1124-1134. http://dx.doi.org/10.1056/NEJMsa050467

Jayashree S, Arindam M and Vijay KV (2015). Genetic epidemiology of coronary artery disease: an Asian Indian perspective. J. Genet. 94: 539-549. http://dx.doi.org/10.1007/s12041-015-0547-4

Jin J, Li W, Peng L, Chen J, et al. (2014). Relationship between interleukin-10 -1082A/G polymorphism and risk of ischemic stroke: a meta-analysis. PLoS One 9: e94631. http://dx.doi.org/10.1371/journal.pone.0094631

Karaca E, Kayıkçıŏglu M, Onay H, Gündüz C, et al. (2011). The effect of interleukin-10 gene promoter polymorphisms on early-onset coronary artery disease. Anadolu Kardiyol. Derg. 11: 285-289.

Li L, Li E, Zhang LH, Jian LG, et al. (2015). IL-6-174G/C and IL-6-572C/G polymorphisms are associated with increased risk of coronary artery disease. Genet. Mol. Res. 14: 8451-8457. http://dx.doi.org/10.4238/2015.July.28.12

Liang C, Du W, Dong Q, Liu X, et al. (2015). Expression levels and genetic polymorphisms of interleukin-2 and interleukin-10 as biomarkers of Graves' disease. Exp. Ther. Med. 9: 925-930.

Lin YJ, Lan YC, Lai CH, Lin TH, et al. (2014). Association of promoter genetic variants in interleukin-10 and Kawasaki disease with coronary artery aneurysms. J. Clin. Lab. Anal. 28: 461-464. http://dx.doi.org/10.1002/jcla.21710

Oikonomou E, Siasos G and Tousoulis D (2014). Pro-inflammatory interleukin genotypes potentiate early and advanced atherosclerosis differently. J. Am. Coll. Cardiol. 64: 848-849. http://dx.doi.org/10.1016/j.jacc.2014.05.043

Ren B and She Q (2015). Study on the association between IL-1 $\beta$, IL-8 and IL-10 gene polymorphisms and risk of coronary artery disease. Int. J. Clin. Exp. Med. 8: 7937-7943.

Shi GL, Cai XX, Su YM, Chen C, et al. (2015a). Interleukin-10 promotor -592A/C polymorphism is associated with slow coronary flow in Han Chinese. Int. J. Clin. Exp. Pathol. 8: 4091-4098.

Shi Y, Zhang J, Tan C, Xu W, et al. (2015b). Matrix metalloproteinase-2 polymorphisms and incident coronary artery disease: a meta-analysis. Medicine (Baltimore) 94: e824. http://dx.doi.org/10.1097/MD.0000000000000824

Sun GQ, Wu GD, Meng Y, Du B, et al. (2014). IL-6 gene promoter polymorphisms and risk of coronary artery disease in a Chinese population. Genet. Mol. Res. 13: 7718-7724. http://dx.doi.org/10.4238/2014.September.26.9

Tang B, Chen YK, Luo WJ, Fu J, et al. (2014). Association between interleukin-10 -1082A/G, -819C/T and $-592 \mathrm{C} /$ A polymorphisms with deep venous thrombosis. Hum. Immunol. 75: 203-207. http://dx.doi.org/10.1016/j. humimm.2013.12.013

Wang Y, Zheng J, Liu P, Yu X, et al. (2012). Association between the Interleukin 10-1082G $>$ A polymorphism and coronary heart disease risk in a Caucasian population: a meta-analysis. Int. J. Immunogenet. 39: 144-150. http:// dx.doi.org/10.1111/j.1744-313X.2011.01072.x

Yang Q, Yin RX, Cao XL, Wu DF, et al. (2015). Association of two polymorphisms in the FADS1/FADS2 gene cluster and the risk of coronary artery disease and ischemic stroke. Int. J. Clin. Exp. Pathol. 8: 7318-7331.

Zhang MM, Xie X, Ma YT, Zheng YY, et al. (2015). Association of COX-2 -765G $>$ C genetic polymorphism with coronary artery disease: a meta-analysis. Int. J. Clin. Exp. Med. 8: 7412-7418.

Zheng XY, Guan WJ, Mao C, Chen HF, et al. (2014). Interleukin-10 promoter 1082/-819/-592 polymorphisms are associated with asthma susceptibility in Asians and atopic asthma: a meta-analysis. Lung 192: 65-73. http://dx.doi. org/10.1007/s00408-013-9519-8 